\title{
HEART-TYPE FATTY ACID-BINDING PROTEIN (H-FABP) AS A NOVEL BIOMARKER FOR THE EARLY DIAGNOSIS OF ACUTE MYOCARDIAL INFARCTION IN COMPARISON WITH CARDIAC TROPONIN T
}

Jagadish H. Ramaiah, Raghu T. Ramegowda, Bharatha Ashalatha, Rajiv Ananthakrishna, Manjunath C. Nanjappa.

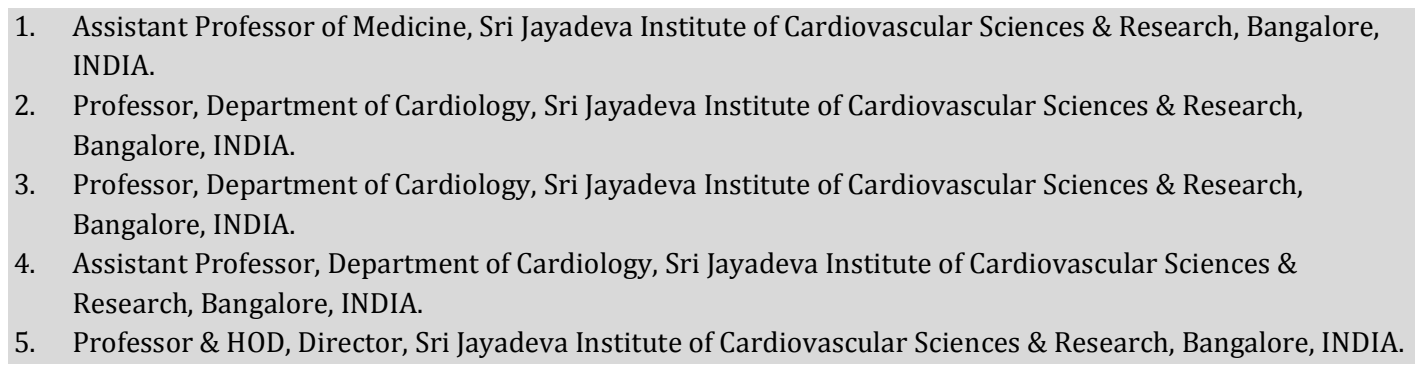

\section{CORRESPONDING AUTHOR}

Dr. Jagadish H. Ramaiah,

Sri Jayadeva Institute of Cardiovascular Sciences \& Research,

Jaya Nagar 9th Block, BG Road, Bangalore

Karnataka, INDIA.

E-mail: jagadishhr@rediffmail.com

Ph: 00919008498880.

ABSTRACT: BACKGROUND AND OBJECTIVE: At very early stages of acute myocardial infarction (AMI), highly sensitive biomarkers are still lacking. Human heart-type fatty acidbinding protein (H-FABP) has a high potential as an early marker for acute myocardial infarction (AMI) being more sensitive than current routine cardiac markers. The objective of this study is to determine the efficacy of a newly developed qualitative test to measure Hearttype fatty acid-binding protein (H-FABP) levels in the blood for the early diagnosis of acute myocardial infarction (AMI) in patients with chest pain and compared with cardiac Troponin T.

DESIGN: Prospective study. METHODS: Fifty patients with acute ischemic-type chest pain were prospectively enrolled and classified according to the American Heart Association/American College of Cardiology guidelines. An initial blood sample was obtained for H-FABP, cTnT, and CK-MB (first 4 hours of symptoms). After 4 hours ( 4 - 12 hours), repeat samples of H-FABP, cTnT, and CK-MB were obtained. RESULTS: Fifty patients presenting to hospital with a median symptom onset of $3.3 \mathrm{hrs}$ (IQR 2-6 h) were enrolled in this study and 38 (76\%) had AMI. At presentation, H-FABP gave the highest sensitivity of 77\% (95\% CI: 60.7-88.9) and specificity of 91\% (95\% CI: 58.7-99.8) and troponin T (cTnT) gave the highest specificity of $100 \%$ (95\% CI: 69.2-100). This study demonstrated that H-FABP immunotest gave a better diagnostic classification at the early stage. Also, AMI was identified significantly earlier by H-FABP than cTnT (29 vs. 8 patients, p<0.05). CONCLUSIONS: Assessment of Heart-type fatty acid-binding protein (H-FABP) within the first $4 \mathrm{~h}$ of symptoms is superior to cTnT for detection of AMI, and is a useful additional biomarker for patients with acute ischemic chest pain.

KEY WORDS: Heart-Type Fatty Acid-Binding Protein; Troponin T; Acute Myocardial Infarction; Biomarkers. 
INTRODUCTION: In patients presenting with ischemic-type chest pain, the early establishment of a definite final diagnosis of acute myocardial infarction (AMI) is crucial for treatment in the emergency department ("timely diagnosis"). For a rapid and accurate diagnosis, the indicators of early coronary pathophysiologic events (i.e., the time of plaque rupture before complete coronary occlusion) are crucial ("early diagnosis"). The ideal biomarker for myocardial ischemia would therefore be indicative early in the cascade of events and allow a prompt diagnosis, aiding therapeutic decisions in the clinical setting 1 . According to the American Heart Association/ American College of Cardiology ST-elevation myocardial infarction (STEMI) and non-STEMI (non-STEMI) guidelines of myocardial infarction, a positive serum level of cardiac troponin is a constituent part of the final diagnosis 2 . However, because of its large molecular size, cardiac troponin $\mathrm{T}$ (cTnT) does not peak until approximately 6 to 12 hours after the onset of symptoms ${ }^{3}$. In addition, the electrocardiogram has only $50 \%$ sensitivity in the diagnosis of $\mathrm{AMI}^{4-5}$.

Heart-type fatty acid-binding protein (H-FABP), a low molecular mass cytoplasmic protein $(15 \mathrm{kD})$ abundant in heart muscle cells, has a high potential as a sensitive biomarker for early diagnosis of AMI ${ }^{6-8}$. H-FABP levels rise as early as 1-3 $\mathrm{h}$ after the onset of AMI, peak at 6-8 $\mathrm{h}$, and return to normal within 24-30 h.

A one-step H-FABP immunochromatographic test so-called QuickSens ${ }^{\circledR}$ designed to detect H-FABP in whole blood samples is now commercially available ${ }^{9-11}$. The test result is available within $15 \mathrm{~min}$ after addition of blood samples. It requires no sample pretreatment and thus can be applied in emergency situation. Combined with the well-established markers, troponins, it may allow more accurate targeting of appropriate therapy and considerable cost savings than the current diagnostic tests. The aim of the present study was to evaluate the diagnostic performance of the H-FABP immunotest in patients suspected with myocardial infarction compared to cardiac troponin T (cTnT) and CK-MB.

\section{METHODS: STUDY POPULATION AND SAMPLE COLLECTION:}

The study took place between December 2010 to March 2011 at Sri Jayadeva Institute of Cardiovascular Sciences and Research Hospital, Bangalore, India. Patients presenting to the Emergency Department (ED) were screened for entry criteria: acute ischemic chest pain within the last $4 \mathrm{~h}$, age $>18$ years. The exclusion criteria were, patients presented after four hours of symptom onset, the inability or unwillingness to give informed consent, age $<18$ years, and interhospital transfer, the renal insufficiency or any renal disease impairing renal clearance, Patients who underwent percutaneous transluminal coronary angioplasty or coronary artery bypass grafting within 30 days; had prior AMI within 30 days; had chronic muscle disease, pulmonary thromboembolism or pericarditis were also excluded. A total of 54 patients met these entry criteria, of whom 50 were included; the reasons for exclusion are listed in Fig. 1.

The clinical parameters assessed included history of cardiac events, physical examination, a recording of a 12-lead ECG, type and duration of symptoms, arteriosclerotic risk factors, and presence of renal impairment (with an estimated glomerular filtration rate of $<30$ $\mathrm{ml} / \mathrm{min}$ ). The time of onset of symptoms was carefully recorded for each patient at presentation. Two blood samples, one at 0 hour (at presentation) and after 4 hours (4-12 hours) of presentation were taken for H-FABP, cTnT \& CK-MB measurement. 


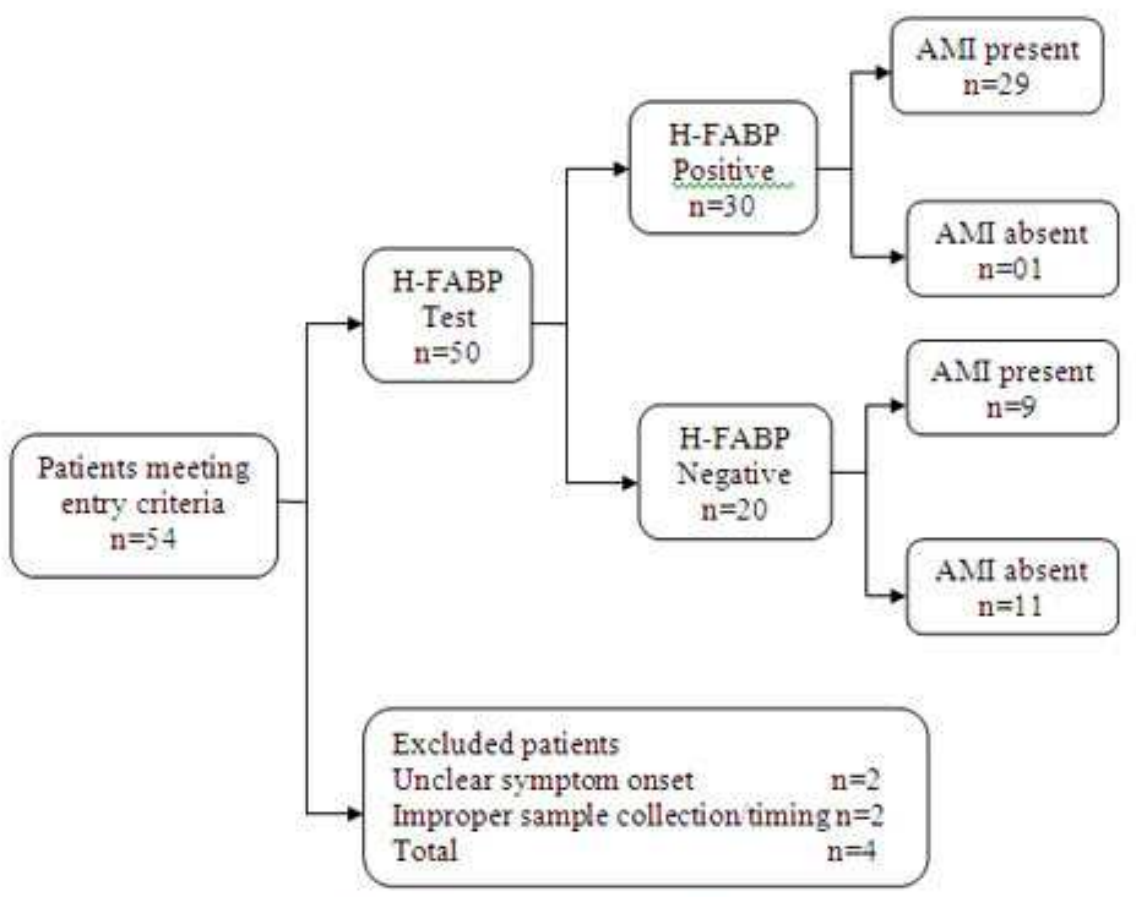

Fig-1. Flow chart of study population at initial presentation

\section{LABORATORY ANALYSIS:}

1. H-FABP Immunotest: A rapid chromatographic immunoassay designed for qualitative determination of H-FABP in blood samples was performed with a cut-off level of $10 \mathrm{ng} / \mathrm{L}$ (QuickSens ${ }^{\circledR}$, 8sens.biognostic GmbH, Berlin, Germany). The test is based on a dual monoclonal antibody sandwich method, using two distinct monoclonal antibodies and the gold labeled method and requires 100-120 $\mu \mathrm{L}$ of blood sample and the result was interpreted within 15 min after sample application. Tests were judged to be positive or negative; invalid tests without control lines were repeated immediately.

2. Troponin T: The serum cTnT levels were measured quantitatively using the Elecsys-2010 troponin $\mathrm{T}$ immunoassay (Troponin T STAT (Short Term Around Time)) (Roche/Hitachi analyzer). The upper reference limit (ninety-ninth percentile) is $0.01 \mathrm{ng} / \mathrm{L}$ and the lowest concentration with a coefficient of variation of $\leq 10 \%$ was $0.03 \mathrm{ng} / \mathrm{L}$.

3. CK-MB (Creatine Kinase-MB): CK-MB (Creatine Kinase-MB liquid) were measured quantitatively using the 912 Roche/Hitachi analyzer, lower limits of measurement $3 \mathrm{U} / \mathrm{L}$, reference value 7-25 $\mathrm{U} / \mathrm{L}$, for $\mathrm{MI}>24 \mathrm{U} / \mathrm{L}$.

ECG ANALYSIS: The initial 12-lead electrocardiograms of all patients. ST elevations $\geq 1$ and $\geq 2$ $\mathrm{mm}$ (at the J point) were noted. ST depression $\geq 0.5 \mathrm{~mm}$ at $80 \mathrm{~ms}$ after the J point and T inversion of $\geq 1.0 \mathrm{~mm}$ at the nadir were classified. Q waves were recorded if $\geq 0.03 \mathrm{~s}$ and $\geq 25 \%$ of the following R. The presence of left bundle branch block was noted separately. 


\section{FINAL DIAGNOSIS:}

1. AMI: AMI was diagnosed when either the cTnT serum levels at admission or at 12 hours were $>0.03 \mathrm{ng} / \mathrm{ml}$, irrespective of the presence of ischemic features on the electrocardiogram in the absence of any other cause for the chest pain ${ }^{12}$. In the absence of cTnT levels at 12 hours, a typical increase and decrease in creatinine kinase levels of more than twice the upper level of normal at 24 hours also confirmed the final diagnosis of AMI (type 1 or 2$)^{2}$. When this definition was met, we then further classified cases as STEMI and non-STEMI according to the electrocardiographic features. STEMI was diagnosed when ST elevation was found in 2 contiguous leads of $>1 \mathrm{mV}$ in leads I to III, aVL, aVF, V5 to V6, and $\geq 2 \mathrm{mV}$ in V1 to V3. Classification of non-STEMI was by exclusion of STEMI.

2. UNSTABLE ANGINA: UA was diagnosed when the history and/or electrocardiographic changes were consistent with an acute coronary syndrome but cTnT negative at 12 hours and/or no typical increase and decrease in creatinine kinase levels at 24 hours. The history parameters included previous myocardial infarction, percutaneous coronary intervention, or coronary artery bypass grafting. The electrocardiographic parameters included significant ischemic changes on the admission electrocardiogram (ST depression $\geq 0.5 \mathrm{mV}$, T inversion $\geq 1$ $\mathrm{mV}$ ) or evidence of coronary artery disease during the index hospital stay (positive coronary angiographic findings, positive stress test).Uninterpretable electrocardiographic tracings (pacemaker, left bundle branch block) did not contribute to the diagnosis of unstable angina but required a positive history of coronary artery disease and/or evidence of coronary artery disease with additional testing.

3. NONISCHEMIC CHEST PAIN: Nonischemic chest pain was diagnosed by the exclusion of AMI and unstable angina.

STATISTICAL ANALYSIS: Data are presented as medians, interquartile ranges (IQR), means \pm standard deviation (SD) or 95\% confidence intervals (95\% CI). Diagnostic test criteria including sensitivity, specificity, negative and positive predictive values, and likelihood ratios were calculated by using MedCalc, version 7.0 (MedCalc Software, Mariakerke, Belgium). McNemar test was used to assess whether H-FABP or cTnI was positive earlier. The level of significance was set at $\mathrm{p}<0.05$

Table-1. Baseline, Clinical, electrocardiographic, and biomarker characteristics at initial presentation

\begin{tabular}{|l|c|c|c|c|}
\hline & $\begin{array}{c}\text { All patients } \\
\mathrm{n}=50\end{array}$ & $\begin{array}{c}\text { AMI } \\
\mathrm{n}=38(76 \%)\end{array}$ & $\begin{array}{c}\text { No AMI } \\
\mathrm{n}=12(24 \%)\end{array}$ & P value \\
\hline $\begin{array}{l}\text { Age (mean } \\
\text { yrs } \pm \mathrm{SD})\end{array}$ & $48.58 \pm 12$ & $49.52 \pm 10$ & $48.62 \pm 14$ & NS \\
\hline Male & $40(80 \%)$ & $33(86.8)$ & $7(58.3)$ & NS \\
\hline Female & $10(20 \%)$ & $5(13.2)$ & $5(41.7)$ & NS \\
\hline $\begin{array}{l}\text { Pain to admission } \\
\text { (hrs) median 95CI }\end{array}$ & $3.3 \mathrm{hrs}(2-6)$ & $2.3 \mathrm{hrs}(1.8-5)$ & $4 \mathrm{hrs}(3-7)$ & NS \\
\hline \multicolumn{4}{|l|}{ Previous history }
\end{tabular}




\begin{tabular}{|c|c|c|c|c|}
\hline a) AMI & $06(12 \%)$ & $05(10 \%)$ & $01(2 \%)$ & NS \\
\hline b) PCI & $02(4 \%)$ & $01(2 \%)$ & $01(2 \%)$ & NS \\
\hline c) CABG & 00 & 00 & 00 & --- \\
\hline d) ANGINA & $02(4 \%)$ & 00 & $02(4 \%)$ & NS \\
\hline Renal failure & 00 & 00 & 00 & --- \\
\hline \multicolumn{5}{|l|}{ Riskfactor } \\
\hline a) DM & $20(40 \%)$ & $16(32 \%)$ & $04(8 \%)$ & NS \\
\hline b) HTN & $22(44 \%)$ & $18(36 \%)$ & $04(8 \%)$ & NS \\
\hline c) Smoker & $28(56 \%)$ & $22(44 \%)$ & $06(12 \%)$ & NS \\
\hline d) Ex-smoker & $04(8 \%)$ & $02(4 \%)$ & $02(4 \%)$ & NS \\
\hline $\begin{array}{l}\text { e) } \begin{array}{l}\text { High } \\
\text { cholesterol }\end{array}\end{array}$ & $32(64 \%)$ & $28(56 \%)$ & $04(8 \%)$ & NS \\
\hline f) FHx of IHD & $04(8 \%)$ & $02(4 \%)$ & $02(4 \%)$ & NS \\
\hline \multicolumn{5}{|l|}{ Admission } \\
\hline a) HR & $72.9 \pm 17.1$ & $75.56 \pm 17.9$ & $77.0 \pm 16.35$ & NS \\
\hline b) Systolic BP & $136.4 \pm 25$ & $133.2 \pm 34.26$ & $134.67 \pm 10.49$ & 0.024 \\
\hline c) Diastolic BP & $71 \pm 16.8$ & $71.44 \pm 18.44$ & $79.0 \pm 13.99$ & NS \\
\hline $\begin{array}{l}\text { d) Typical chest } \\
\text { pain }\end{array}$ & 40 & 36 & 08 & NS \\
\hline $\begin{array}{l}\text { e) Atypical chest } \\
\text { pain }\end{array}$ & 10 & 02 & 04 & NS \\
\hline \multicolumn{5}{|l|}{ ECG-initial findings } \\
\hline a) ST elevation & $32(64 \%)$ & $32(84.2 \%)$ & 00 & ---- \\
\hline $\begin{array}{l}\text { b) ST depression / } \\
\text { T inversion }\end{array}$ & $14(28 \%)$ & $04(10.52 \%)$ & $08(66.6 \%)$ & ---- \\
\hline c) LBBB & $01(2 \%)$ & $01(2.63 \%)$ & 00 & --- \\
\hline d) Normal & $02(4 \%)$ & 00 & $04(33.3 \%)$ & ---- \\
\hline e) Arrhythmia & $01(2 \%)$ & $01(2.63 \%)$ & 00 & ---- \\
\hline \multicolumn{5}{|l|}{ Initial biomarkers } \\
\hline a) $\mathrm{H}-\mathrm{FABP}+$ & $30(60 \%)$ & $29(76 \%)$ & $01(8.3 \%)$ & $<0.001$ \\
\hline b) cTnT + & $08(16 \%)$ & $08(21 \%)$ & 00 & $<0.001$ \\
\hline c) CK-MB + & $04(8 \%)$ & $04(10.5 \%)$ & 00 & $<0.001$ \\
\hline
\end{tabular}

AMI: acute myocardial infarction; CABG: coronary artery bypass grafting; PCI: percutaneous coronary intervention.

RESULTS AND DISCUSSION: Between December 2010 and March 2011, a total of 50 patients were enrolled out of 54 patients meeting the entry criteria (Fig. 1). Mean age was $48.58 \pm 12$ years and $40(80 \%)$ were male. Median time from symptom onset to first blood sample was 3.3 hrs (IQR 2-6 h). 22 patients (44\%) had hypertension, 20 (40\%) had diabetes, none had chronic renal failure (CRF), and there was no deaths during their hospital stay. Acute myocardial infarction was diagnosed in 38 (76\%) individuals, of whom 34 (68\%) had STEMI and 4 (8\%) had NSTEMI. The non-AMI group consisted of 12 patients with a final diagnosis of hypertension, stable angina, pneumonia, paroxysmal ventricular tachycardia, reflux oesophagitis, and Gastric ulcer. 
Table - 2.Management and final treatment of patients with acute chest pain

\begin{tabular}{|c|c|c|c|c|}
\hline & $\begin{array}{c}\text { All patients } \\
(\mathrm{n}=50 ; 100 \%)\end{array}$ & $\begin{array}{c}\text { AMI } \\
(\mathrm{n}=38 ; 76 \%)\end{array}$ & $\begin{array}{c}\text { No AMI } \\
(\mathrm{n}=12 ; 24 \%)\end{array}$ & $P$ value \\
\hline \multicolumn{5}{|l|}{ Acute management } \\
\hline a) In-patient & $44(88 \%)$ & $38(100 \%)$ & $06(50 \%)$ & 0.05 \\
\hline b) ICU-2 & $29(58 \%)$ & $29(76.3 \%)$ & 00 & $<0.05$ \\
\hline c) ICU-3 & $15(30 \%)$ & $09(23.6 \%)$ & $06(50 \%)$ & $<0.05$ \\
\hline Coronary angiography & $35(70 \%)$ & $32(84 \%)$ & $03(25 \%)$ & NS \\
\hline $\begin{array}{l}\text { a) Interval to } \\
\text { Catheterization (hrs) } \\
\text { (median,95 \%CI) }\end{array}$ & $\begin{array}{c}\text { 36hrs (17.6- } \\
62.3)\end{array}$ & $\begin{array}{c}24 \mathrm{hrs} \\
(15.4-58.3)\end{array}$ & $\begin{array}{c}52 \mathrm{hrs} \\
(19.6-78.5)\end{array}$ & NS \\
\hline b) Normal coronaries & $02(5.7 \%)$ & $01(3 \%)$ & $01(33 \%)$ & NS \\
\hline c) SVD & $24(68.5 \%)$ & $23(72 \%)$ & $01(33 \%)$ & NS \\
\hline d) DVD & $04(11.4 \%)$ & $03(9.3 \%)$ & $01(33 \%)$ & NS \\
\hline e) TVD & $05(14.2 \%)$ & $05(15.6 \%)$ & 00 & NS \\
\hline \multicolumn{5}{|c|}{ Revascularization/treatment } \\
\hline a) PCI & $22(44 \%)$ & $20(5.2 \%)$ & $02(16.6 \%)$ & $<0.05$ \\
\hline b) CABG & $04(8 \%)$ & $04(10.5 \%)$ & 00 & NS \\
\hline c) Conservative & $24(48 \%)$ & 14 & $10(83.3 \%)$ & $<0.05$ \\
\hline
\end{tabular}

ICU = Intensive care unit admission for thrombolysis, circulatory or respiratory stabilization.

DIAGNOSTIC PERFORMANCE OF H-FABP IMMUNOTEST: The sensitivity and specificity of HFABP at presentation ( $\leq 4 \mathrm{hrs}$ ) and after $4 \mathrm{hrs}$ were $77 \%$ and $91 \%, 82 \%$ \& $91 \%$ respectively. There were no differences in terms of age, gender, history, risk factors or ECG features in terms of h-FABP performance. However early presenter were very less likely to have sensitive initial cTnT test.

COMPARISON OF H-FABP AND CTNI: The sensitivity of cTnT at presentation was lowest (20\%) when the symptom duration was $<4$ hours and increased to $95 \%$ when the symptom duration was $>4$ hours. The sensitivity of H-FABP for AMI was superior to cTnT for patients admitted within 4 hours of symptom onset. The sensitivity of H-FABP was greatest at 2 to 4 hours after symptom onset and decreased after $>8$ hours. In contrast, cTnT maintained a sensitivity of $95 \%$ at later points. The improvement in sensitivity of cTnT for AMI could be maintained at later points. The specificity of H-FABP, however was significantly lower than cTnT in all subgroups and for all periods. In 8 patients both H-FABP and cTnI were positive, HFABP was positive earlier than CTnI in 29 patients. In this study, we demonstrated that H-FABP was positive significantly earlier than CTnI. All the patients presented to hospital within $4 \mathrm{hrs}$ after symptom onset, when H-FABP might already be detectable, but not cTnI. 
Table-3. Sensitivities, specificities, likelihood values and predictive values of different cardiac markers for diagnosis of AMI.

\begin{tabular}{|l|c|c|c|c|c|c|}
\hline \multirow{2}{*}{} & \multicolumn{2}{|c|}{ H-FABP } & \multicolumn{2}{c|}{ Troponin T } & \multicolumn{2}{c|}{ CK-MB } \\
\cline { 2 - 7 } & $\begin{array}{c}\text { On } \\
\text { admission } \\
\leq 4 \mathrm{hrs}\end{array}$ & $\begin{array}{c}\text { After 4 hrs } \\
(4-12 \mathrm{~h})\end{array}$ & $\begin{array}{c}\text { On } \\
\text { admission } \\
\leq 4 \mathrm{hrs}\end{array}$ & $\begin{array}{c}\text { After 4 hrs } \\
(4-12 \mathrm{~h})\end{array}$ & $\begin{array}{c}\text { On } \\
\text { admission } \\
\leq 4 \mathrm{hrs}\end{array}$ & $\begin{array}{c}\text { After 4 hrs } \\
(4-12 \mathrm{~h})\end{array}$ \\
\hline $\begin{array}{l}\text { Sensitivity } \\
{[\%](95 \% \mathrm{CI})}\end{array}$ & $\begin{array}{c}76.92 \\
(60.7-88.9)\end{array}$ & $\begin{array}{c}82.05 \\
(66.5-92.5)\end{array}$ & $\begin{array}{c}20 \\
(9.1-35.6)\end{array}$ & $\begin{array}{c}95 \\
(83.1-99.4)\end{array}$ & $\begin{array}{c}10 \\
(2.8-23.7)\end{array}$ & $\begin{array}{c}75 \\
(58.8-87.3)\end{array}$ \\
\hline $\begin{array}{l}\text { Specificity } \\
{[\%](95 \% \mathrm{CI})}\end{array}$ & $\begin{array}{c}90.91 \\
(58.7-99.8)\end{array}$ & $\begin{array}{c}90.91 \\
(58.7-99.8)\end{array}$ & $\begin{array}{c}100 \\
(69.2-100)\end{array}$ & $\begin{array}{c}100 \\
(69.2-100)\end{array}$ & $\begin{array}{c}100 \\
(69.2-100)\end{array}$ & $\begin{array}{c}100 \\
(69.2-100)\end{array}$ \\
\hline $\begin{array}{l}\text { Positive } \\
\text { predictive } \\
\text { value[\%] }\end{array}$ & 96.8 & 97 & 100 & 100 & 100 & 100 \\
\hline $\begin{array}{l}\text { negative } \\
\text { predictive } \\
\text { value[\%] }\end{array}$ & 52.63 & 58.82 & 23.8 & 83.3 & 21.7 & 50 \\
\hline LR[+] & 8.46 & 9.03 & 1.0 & 1.0 & 1.0 & 1.0 \\
\hline LR[-] & 0.25 & 0.2 & 0.8 & 0.05 & 0.9 & 0.25 \\
\hline
\end{tabular}

SENSITIVITIES, SPECIFICITIES AND PREDICTIVE VALUES FOR DIFFERENT CARDIAC MARKERS: The sensitivities and specificities of different cardiac markers are listed in Table 3. H-FABP gave the highest sensitivity (77\%) for early exclusion of non-AMI patients, whereas cTnI gave the highest specificity (100\%) for inclusion of AMI patients. The respective sensitivities of H-FABP, cTnT and CK-MB were 77\%, 20\%, and 10\% $(\mathrm{p}<0.05)$ for patients presenting within 4 hours and for $>4$ hours were $82 \%, 95 \%, 75 \%$ respectively. The respective specificities were 91\%, 100\%, 100\%, ( $\mathrm{p}<0.05)$ for within 4 hours and $>4$ hours $(4-12)$.

CORONARY ANGIOGRAPHY \& REVASCULARIZATION: Among 38 patients of AMI, 32 undergone coronary angiogram out of this, 23 patients had single vessel disease(SVD), 30 patients had DVD, 5 had TVD, 1 patients had normal coronaries \& 20 patients had undergone PTCA(10 LAD, 8 RCA, 2 LCX) 4 had Coronary Artery Bypass Graft (CABG) surgery \& 14 patients were medical managed.

RECEIVER OPERATOR CHARACTERISTIC CURVES FOR DIFFERENT CARDIAC MARKERS:

The areas under the receiver operator characteristic (ROC) curves to distinguish AMI from nonAMI within $4 \mathrm{hrs}$ after the onset of symptoms were $0.83 \pm 0.05$ (95\% CI: $0.70-0.92$ ) for H-FABP, $0.55 \pm 0.02(0.40-0.69)$ for CK-MB, and $0.60 \pm 0.03$ (95\% CI: $0.45-0.73)$ for cTnI. The area under the curve for H-FABP was significantly greater than those of the other cardiac markers within 4 hrs after the onset of symptoms. Thus, H-FABP has great potential as an excellent cardiac marker for diagnosis of AMI in the early phase. 
Table-4. Area under receiver operating characteristic curves (z-statistic)

\begin{tabular}{|c|c|c|c|c|c|c|c|c|}
\hline \multirow{2}{*}{$\begin{array}{c}\text { Biomarke } \\
\mathbf{r}\end{array}$} & \multicolumn{3}{|c|}{ Patients admitted $\leq 4$ hrs from symptom } & \multicolumn{3}{c|}{ Patients admitted $\geq 4$ hrs from symptom } \\
onset & AUC \pm SE & $\begin{array}{c}\text { Z } \\
\text { statistic }\end{array}$ & $95 \%$ CI & P value & AUC \pm SE & $\begin{array}{c}\text { Z } \\
\text { statistic }\end{array}$ & $95 \%$ CI & P value \\
& & & & & & & & \\
\hline H-FABP & $0.83 \pm 0.05$ & 5.96 & $0.70-0.92$ & $<0.0001$ & $0.86 \pm 0.05$ & 6.62 & $0.73-0.94$ & $<0.0001$ \\
\hline CTnT & $0.60 \pm 0.03$ & 3.12 & $0.45-0.73$ & 0.0018 & $0.97 \pm 0.01$ & 27.22 & $0.88-0.99$ & $<0.0001$ \\
\hline CK-MB & $0.55 \pm 0.02$ & 2.08 & $0.40-0.69$ & 0.0374 & $0.87 \pm 0.03$ & 10.81 & $0.75-0.95$ & $<0.0001$ \\
\hline
\end{tabular}

CI: Confidence Intervals

DISCUSSION:The use of biomarkers aids in the process of diagnosing myocardial infarction in the emergency department and helps in risk stratification of patients, allowing appropriate treatment to be given, and has proved superior to electrocardiographic guidance alone ${ }^{1}$. Cardiac troponins have revolutionized in decision making and led to a redefinition of myocardial infarction in $2000^{12}$ that included elevated troponins as an obligatory diagnostic criterion. With respect to revascularization, the period for optimal treatment is within the first 4 hours after the onset of plaque rupture. However, a number of studies have reported a low sensitivity of cardiac troponins in the first 6 to 12 hours $^{3,12-14}$. The data of the present study have confirmed the early sensitivity issue of cTnT.

In a number of studies, H-FABP has been reported to be particularly sensitive within the first few hours after the onset of coronary occlusion and symptoms ${ }^{15-20}$. The reason for this high sensitivity has been explained by its small molecular weight $(15 \mathrm{kDa})$ and its cytoplasmic unbound abundance, resulting in rapid release from damaged myocardial cells 6 . A high sensitivity early in myocardial infarction has been noted in several, mainly selected, study population groups, demonstrating a promising potential role of H-FABP as a decision tool in the early diagnosis of myocardial infarction ${ }^{21-24}$. The release characteristics of H-FABP after occlusive AMI showed elevated serum concentrations 30 to 90 minutes after the onset of symptoms, with peak levels reached at 4 to 6 hours, and normalization of serum levels to baseline levels owing to rapid renal clearance within 20 hours. The data of the present study support the idea that H-FABP is a sensitive marker in the first 4 hours after symptom onset. Given the relatively high prevalence of AMI in the study population, high sensitivity translated into high negative predictive values for H-FABP, suggesting a possible use of this marker, especially for the early rule out of AMI.

The low H-FABP specificity of (90\%) compare with cTnT(100\%) may be attributed to numerous factors first, renal insufficiency however present study there were no renal failure patients. Second, H-FABP can be released from ischemic myocardium, as well as from infracted myocardium 6 .

Third, H-FABP release of noncardiac origin might play a role in patients with acute chest pain and H-FABP is also present in the skeletal muscle and other tissues at low concentrations ${ }^{6,24}$, although relative cardiospecificity is generally reported to be much greater than for myoglobin or creatinine kinase-MB. No study data on recent physical activity, injury, noncardiac surgery, or intramuscular injections were collected to address this issue.

Patients with AMI presented with a symptom duration of $<4$ hours, H-FABP performed significantly better than cTnT as a marker to differentiate between acute STEMI and non-AMI conditions. When analyzing patients with non-STEMI, however, we found that H-FABP 
performed particularly poorly, irrespective of symptom duration. Because non-STEMI is a diagnostic model reflecting a thrombembolic, often repetitive, microvascular occlusion from an upstream thrombus-laden ruptured plaque, misclassification by H-FABP testing could be attributed to the small amounts of H-FABP being rapidly cleared from serum in contrast to the large molecular cTnT, which cumulates to finally maintain elevated serum levels. A gain in sensitivity of a rapid-release biomarker in the early phase of STEMI could be explained if the affected myocardial mass is large enough. Confining electrocardiographic interpretation to discriminating normal from abnormal initial electrocardiographic tracings, H-FABP proved a usable predictor of AMI in cTnT-negative patients with abnormal electrocardiographic findings and early presentation within the first 4 hours after symptom onset.

\section{LIMITATIONS:}

1) The sample size of the total study population was too small to allow for a generalization of the results. However, the study results are in accordance with the reported test characteristics of H-FABP25-26, and the investigation was aimed at testing the potential role of H-FABP in early risk stratification of acute ischemic-type of chest pain in the clinical setting of a real world emergency department.

2) This study only studied the potential benefit from a twice measurement of H-FABP at admission and after $4 \mathrm{hrs}$, sequential measurements were not performed.

3) A multimarker approach (including biomarkers of concomitant cardiac conditions, such as proBNP, myoglobin) was not taken, which could have further elucidated the falsepositive rate in H-FABP testing. However, the present study was designed with cTnT and CK-MB as the comparator, and priority was given to determine whether H-FABP added significant information to aid in the clinical assessment of patients with acute ischemic type of chest pain.

CONCLUSION: In this study, we aimed to evaluate the accuracy of HFABP in a point-of-care setting for early diagnosis of myocardial damage in patients presenting to the ED suspected of AMI. For patients presenting within $4 \mathrm{~h}$ of symptom onset the sensitivity of H-FABP is significantly higher than CTnT. H-FABP could not by itself diagnose AMI with adequately high accuracy, but when positive, it was usually faster than cTnT. In order to decrease the risk of falsely excluded patients with ongoing AMI, a combined measurement of two biochemical markers, an early one such as HFABP and a later marker such as troponins may provide the optimum diagnostic performance.

ACKNOWLEDGEMENTS: We thank 8sens.biognostic GmbH, Berlin, Germany for donation of QuickSens ${ }^{\circledR}$ h-FABP.

\section{REFERENCES:}

1. Christenson RH, Azzazy HME. Biomarkers of myocardial necrosis past, present, and future. In: Morrow DA, ed. Cardiovascular Biomarkers: Pathophysiology and Disease Management. Totowa, NJ: Humana Press; 2006:3-25.

2. Thygesen K, Alpert JS, et.al. Universal definition of myocardial infarction. Circulation $2007 ; 116: 2634-2653$. 
3. Panteghini M, Pagani F, Bonetti G. The sensitivity of cardiac markers: an evidence-based approach. Clin Chem Lab Med 1999;37:1097-1106.

4. Salerno SM, Alguire PC, Waxman HS. Competency in interpretation of 12-lead electrocardiograms: a summary and appraisal of published evidence. Ann Intern Med 2003;138:751-760.

5. Wagner GS, Macfarlane P, Wellens H, Josephson M, Gorgels A, Mirvis DM, Pahlm O, Surawicz B, Kligfield P, Childers R, Gettes LS, Bailey JJ, Hancock EW, Mason JW, Rautaharju PM, AHA/ACCF/HRS recommendations for th standardization and interpretation of the electrocardiogram. Part VI. Acute ischemia/infarction: a scientific statement from the American Heart Association Electrocardiography and Arrhythmias Committee, Council on Clinical Cardiology; the American College of Cardiology Foundation; and the Heart Rhythm Society. Endorsed by the International Society for Computerized Electrocardiology. J Am Coll Cardiol 2009;53:1003-1011.

6. Glatz JFC, Van der Voort D, Hermens WT. Fatty acid-binding protein as the earliest available plasma marker of acute myocardial injury. J Clin Ligand Assay 2002;25:16777.

7. Nakata T, Hashimoto A, Hase M, Tsuchihashi K, Shimamoto K. Human heart-type fatty acid-binding protein as an early diagnostic and prognostic marker in acute coronary syndrome. Cardiology 2003;99:96-104.

8. Chan CP, Sanderson JE, Glatz JFC, Cheng WS, Hempel A, Renneberg R. A superior early myocardial infarction marker. Human heart-type fatty acid-binding protein. Z Kardiol 2004;93:388-97.

9. Chan CP , Lehmann M, Renneberg I, et al. A Novel Credit-Card Style Assay for Beside Determination of Fatty Acid- Binding Protein. IVD Technology Magazine 2006;12:51.

10. Chan CP, Cheng WS, Glatz JFC, et al. Early diagnosis of acute myocardial infraction using immunosensors and immunotests. J Anal Lett 2003;36:1987-2004.

11. Chan CP, Sum KW, Cheung KY, et al. Development of a quantitative lateral-flow assay for rapid detection of fatty acid-binding protein. J Immunol Methods 2003;279:91-100.

12. Alpert JS, Thygesen K, Antman E, Bassand JP. Myocardial infarction redefined-a consensus document of the joint European Society of Cardiology/American College of Cardiology Committee for the redefinition of myocardial infarction. J Am Coll Cardiol 2000; 36:959-969.

13. Tucker JF, Collins RA, Anderson AJ, Hauser J, Kalas J, Apple FS. Early diagnostic efficiency of cardiac troponin I and troponin T for acute myocardial infarction. Acad Emerg Med 1997;4:13-21.

14. Balk EM, Ioannidis JP, Salem D, Chew PW, Lau J. Accuracy of biomarkers to diagnose acute cardiac ischemia in the emergency department: a meta-analysis. Ann Emerg Med 2001;37:478-494.

15. Mad P, Domanovits H, Fazelnia C, Stiassny K, Russmuller G, Cseh A, Sodeck G, Binder T, Christ G, Szekeres T, Laggner A, Herkner H. Human heart-type fatty acid-binding protein as a point-of-care test in the early diagnosis of acute myocardial infarction. QJM 2007;100: 203-210.

16. McCann CJ, Glover BM, Menown IB, Moore MJ, McEneny J, Owens CG, Smith B, Sharpe PC, Young IS, Adgey JA. Novel biomarkers in early diagnosis of acute myocardial infarction compared with cardiac troponin T. Eur Heart J 2008;29:2843-2850.

17. Ruzgar O, Bilge AK, Bugra Z, Umman S, Yilmaz E, Ozben B, Umman B, Meric M. The use of human heart-type fatty acid-binding protein as an early diagnostic biochemical marker of myocardial necrosis in patients with acute coronary syndrome, and its comparison with troponin- T and creatine kinase-myocardial band. Heart Vessels 2006;21: 309-314.

18. Valle HA, Riesgo LG, Bel MS, Gonzalo FE, Sanchez MS, Oliva LI. Clinical assessment of heart-type fatty acid binding protein in early diagnosis of acute coronary syndrome. Eur J Emerg Med 2008;15: 140-144. 
19. Nakata T, Hashimoto A, Hase M, Tsuchihashi K, Shimamoto K. Human heart-type fatty acid-binding protein as an early diagnostic and prognostic marker in acute coronary syndrome. Cardiology 2003;99: 96-104.

20. Seino Y, Ogata K, Takano T, Ishii J, Hishida H, Morita H, Takeshita H, Takagi Y, Sugiyama H, Tanaka T, Kitaura Y. Use of a whole blood rapid panel test for heart-type fatty acidbinding protein in patients with acute chest pain: comparison with rapid troponin $\mathrm{T}$ and myoglobin tests. Am J Med 2003; 115:185-190.

21. Ecollan P, Collet JP, Boon G, Tanguy ML, Fievet ML, Haas R, Bertho N, Siami S, Hubert JC, Coriat P, Montalescot G. Pre-hospital detection of acute myocardial infarction with ultrarapid human fatty acid-binding protein (H-FABP) immunoassay. Int J Cardiol 2007;119:349 -354.

22. Liao J, Chan CP, Cheung YC, Lu JH, Luo Y, Cautherley GW, Glatz JF, Renneberg R. Human heart-type fatty acid- binding protein for on-site diagnosis of early acute myocardial infarction. Int J Cardiol 2008;133:420-423.

23. Mad P, Domanovits H, Fazelnia C, Stiassny K, Russmuller G, Cseh A, Sodeck G, Binder T, Christ G, Szekeres T, Laggner A, Herkner H. Human heart-type fatty acid-binding protein as a point-of-care test in the early diagnosis of acute myocardial infarction. QJM 2007;100: 203-210.

24. Ruzgar O, Bilge AK, Bugra Z, Umman S, Yilmaz E, Ozben B, Umman B, Meric M. The use of human heart-type fatty acid-binding protein as an early diagnostic biochemical marker of myocardial necrosis in patients with acute coronary syndrome, and its comparison with troponin- T and creatine kinase-myocardial band. Heart Vessels 2006;21: 309-314.

25. Alhadi HA, Fox KA. Do we need additional markers of myocyte necrosis: the potential value of heart fatty-acid binding protein. QJM 2004;97:187-198.

26. McCann CJ, Glover BM, Menown IB, Moore MJ, McEneny J, Owens CG, Smith B, Sharpe PC, Young IS, Adgey JA. Novel biomarkers in early diagnosis of acute myocardial infarction compared with cardiac troponin T. Eur Heart J 2008;29:2843-2850. 